\title{
Congenital asymptomatic absence of unilateral sternocleidomastoid muscle
}

\author{
Hitendra Prakash Singh, Sunil Kumar, Satya Prakash Agarwal
}

Department of ENT and HeadNeck Surgery, King George's Medical University, Lucknow, Uttar Pradesh, India

\section{Correspondence to}

Dr Hitendra Prakash Singh, drhpsingh77@gmail.com
CrossMark

To cite: Singh HP, Kumar $S$, Agarwal SP. BMJ Case Rep Published online: [please include Day Month Year] doi:10.1136/bcr-2013202786

\section{DESCRIPTION}

A 56-year-old man visited the ENT (ear-nose-throat) department for his left earache, which revealed the diagnosis of acute otitis externa of fungal origin. He was given standard treatment of aural toilet, antifungal ear drops and analgesics. During routine examination, it was observed that the patient had no sternocleidomastoid muscle on his right side (figure 1). His neck movements were normal (figure 2). There was no history of trauma, surgery or pain in the neck. Rest of the examination was within normal limits. The patient reported that he had had this disfiguration since childhood and did not suffer any functional deficit. He did not agree for further investigations. A literature search was performed, which did not reveal any report of such occurrence without any functional deficit at this age. $^{12}$

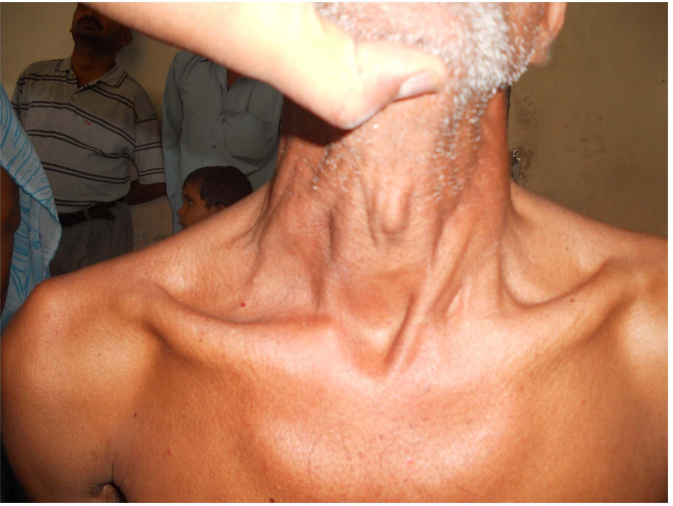

Figure 1 Front view of the neck showing complete absence of sternocleidomastoid muscle on the right side.

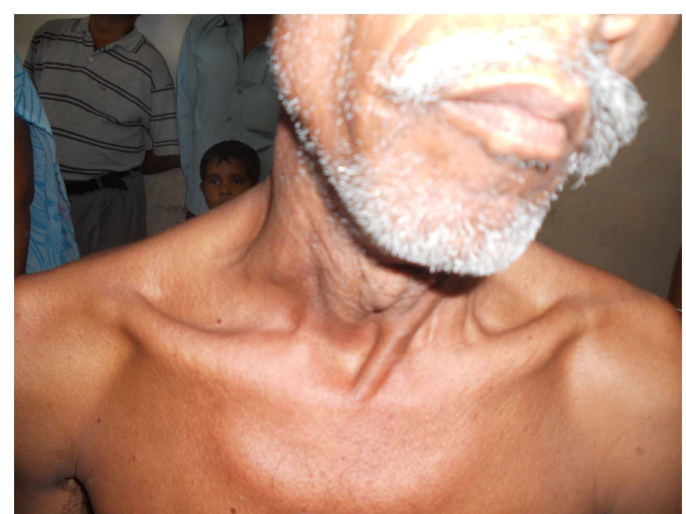

Figure 2 Front view of the neck showing normal neck movements.

\section{Learning points}

- Absence of sternocleidomastoid muscle is a rare clinical entity.

- It may present at a later age in life without any functional deficit.

\section{Competing interests None.}

Patient consent Obtained.

Provenance and peer review Not commissioned; externally peer reviewed.

\section{REFERENCES}

1 Vajramani A, Witham FM, Richards RH. Congenital unilateral absence of sternocleidomastoid and trapezius muscles: a case report and literature review. J Pediatr Orthop B 2010;19:462-4.

2 Bayne SR, Lehman JA, Crow JP. Lung herniation into the neck associated with congenital absence of the sternocleidomastoid muscle. J Pediatr Surg 1997:32:1754-6.

Copyright 2014 BMJ Publishing Group. All rights reserved. For permission to reuse any of this content visit http://group.bmj.com/group/rights-licensing/permissions.

BMJ Case Report Fellows may re-use this article for personal use and teaching without any further permission.

Become a Fellow of BMJ Case Reports today and you can:

- Submit as many cases as you like

- Enjoy fast sympathetic peer review and rapid publication of accepted articles

- Access all the published articles

- Re-use any of the published material for personal use and teaching without further permission

For information on Institutional Fellowships contact consortiasales@bmjgroup.com

Visit casereports.bmj.com for more articles like this and to become a Fellow 